\title{
CORRIGENDUM: RULE OF LAW VS. POLAND AND HUNGARY - AN INCONSISTENT APPROACH?
}

\author{
NASIYA DAMINOVA*
}

Postdoctoral Researcher, Lehrstuhl für Öffentliches Recht mit internationaler Ausrichtung, Universität Konstanz, PhD in Comparative and Transnational Law, Scuola Superiore Sant 'Anna (2018),

Konstanz, Germany.

\section{CORRIGENDUM}

Published online: June 8, 2021

(C) 2021 Akadémiai Kiadó, Budapest

CORRIGENDUM: Hungarian Journal of Legal Studies 60 (2019) 3, 236-259

DOI: $10.1556 / 2052.2019 .00015$

The following acknowledgement was regrettably omitted from the original publication.

\section{ACKNOWLEDGEMENT}

This publication has received funding from the European Union's Horizon 2020 research and innovation programme under the grant agreement No. 822590-Democratic Efficacy and the Varieties of Populism in Europe (DEMOS). Any dissemination of results here presented reflects only the author's view. The Agency is not responsible for any use that may be made of the information it contains.

\footnotetext{
* Corresponding author. E-mail: nasiya.daminova@gmail.com
} 